\title{
Myocardial salvage and infarct size in acute myocardial infarction assessed by magnetic resonance imaging - Influences by prehospital initiated facilitated PCl versus primary $\mathrm{PCl}$ in early infarct presenters

\author{
Holger Thiele*, Ingo Eitel, Claudia Meinberg, Matthias Gutberlet and \\ Gerhard Schuler
}

Address: University of Leipzig - Heart Center, Leipzig, Germany

* Corresponding author

from 13th Annual SCMR Scientific Sessions

Phoenix, AZ, USA. 2I-24 January 2010

Published: 21 January 2010

Journal of Cardiovascular Magnetic Resonance 2010, I2(Suppl I):P206 doi:I0.I I86/I532-429X-I2-SI-P206

This abstract is available from: http://jcmr-online.com/content/I2/SI/P206

(c) 2010 Thiele et al; licensee BioMed Central Ltd.

\begin{abstract}
Introduction
Myocardial salvage (MS) can be assessed retrospectively by $\mathrm{T} 2$-weighted and delayed enhancement images as shown in animal studies. Currently there is limited data in humans and this technique has not been used for the assessment in multicenter trials comparing different reperfusion regimens in STEMI. Facilitated PCI with fibrinolysis did not show a benefit in comparison to primary PCI in recently published trials. However, a subgroup of high-risk STEMI patients presenting early after symptom onset, treated with optimal antiplatelet co-medication, and with long transfer times might benefit from a fibrinolytic-based facilitated PCI.
\end{abstract}

\section{Purpose}

Aim of this trial was to establish MS imaging as a surrogate endpoint in a randomized multicenter trial and to show that facilitated PCI versus primary PCI in a STEMI network with long transfer distances up to $70 \mathrm{~km}$ is beneficial with respect to infarct size (IS) and MS.

\section{Methods}

Patients with STEMI ( $<3 \mathrm{~h}$ after symptom onset) were randomized to either prehospital initiated facilitated PCI using tenecteplase (group $\mathrm{A} ; \mathrm{n}=81$ ) or primary PCI (group $\mathrm{B} ; \mathrm{n}=81$ ). Optimal prehospital co-medication consisted of $600 \mathrm{mg}$ clopidogrel loading-dose plus aspi- rin. The primary endpoint was IS assessed by delayed enhancement. Secondary endpoints were microvascular obstruction and MS assessed by MRI, ST-resolution at 90 min., and a composite of death, re-MI, and congestive heart failure at 30 day follow-up.

\section{Results}

All images were assessable for the calculation of the MS index. The median time from symptom-onset to randomization was $64 \mathrm{~min}(\mathrm{IQR} 42 ; 103)$ in group A versus $55 \mathrm{~min}$ in group B (IQR 27;91; $\mathrm{p}=0.26)$. Despite better preinterventional TIMI-flow in group A (76\% versus $28 \%$ TIMI 2 or $3 ; \mathrm{P}<0.001)$ IS size was similar in group A versus $\mathrm{B}$ (14.1\% of left ventricle [IQR $5.3 ; 26.7$ ] versus $15.1 \%$ [IQR $7.5 ; 23.3] ; \mathrm{p}=0.75)$. There was also no difference in microvascular obstruction, MS ( $\mathrm{p}=0.65$ and 0.71$)$ and a trend towards worse ST-segment resolution $(\mathrm{p}=0.07)$. The combined clinical endpoint showed a trend towards higher event rates in group A $(18.9 \%$ versus $8.1 \%$; $\mathrm{p}=$ 0.09 , relative risk $2.33,95 \%$ confidence interval, 0.98 $5.63)$.

\section{Conclusion}

MRI can reliably measure MS retrospectively and served as a surrogate endpoint in this randomized multicenter clinical trial. This trial failed to show that in patients with STEMI - presenting early after symptom onset with rela- 
tively long transfer times - a fibrinolytic-based facilitated PCI approach with optimal antiplatelet co-medication offers any benefit over primary PCI with respect to IS and tissue perfusion.

Publish with Bio Med Central and every scientist can read your work free of charge

"BioMed Central will be the most significant development for disseminating the results of biomedical research in our lifetime. " Sir Paul Nurse, Cancer Research UK

Your research papers will be:

- available free of charge to the entire biomedical community

- peer reviewed and published immediately upon acceptance

- cited in PubMed and archived on PubMed Central

- yours - you keep the copyright 